\title{
Amphibians from Santa Isabel do Rio Negro, Brazilian Amazonia
}

\author{
Marcelo Menin,,${ }^{1,2}$ Vinicius Tadeu de Carvalho, ${ }^{3}$ Alexandre P. Almeida, ${ }^{2}$ Marcelo Gordo, ${ }^{1,2}$ Deyla \\ P. Oliveira, ${ }^{4,5}$ Luciana F. Luiz, ${ }^{1,3}$ Juliana V. Campos, ${ }^{6}$ and Tomas Hrbek ${ }^{2,7}$ \\ ${ }^{1}$ Departamento de Biologia, Instituto de Ciências Biológicas, Universidade Federal do Amazonas, Avenida General Rodrigo \\ Otávio Jordão Ramos 6200, 69077-000, Manaus, AM, Brazil. E-mail: menin@ufam.edu.br. \\ ${ }^{2}$ Programa de Pós-Graduação em Zoologia, Universidade Federal do Amazonas, Avenida General Rodrigo Otávio Jordão \\ Ramos 6200, 69077-000, Manaus, AM, Brazil. \\ ${ }^{3}$ Programa de Pós-Graduação em Biodiversidade e Biotecnologia, Universidade Federal do Amazonas, Avenida General \\ Rodrigo Otávio Jordão Ramos 6200, 69077-000, Manaus, AM, Brazil. \\ ${ }^{4}$ Programa de Pós-Graduação em Genética, Conservação e Biologia Evolutiva, Instituto Nacional de Pesquisas da Amazônia, \\ Avenida André Araújo 2936, 69067-375, Manaus, AM, Brazil. \\ ${ }_{5}^{5}$ Departamento de Biologia, Universidade Federal do Tocantins, Plano Diretor Norte s/n, 77001-923, Palmas, TO, Brazil. \\ ${ }^{6}$ Programa de Pós-Graduação em Diversidade Biológica, Universidade Federal do Amazonas, Avenida General Rodrigo \\ Otávio Jordão Ramos 6200, 69077-000, Manaus, AM, Brazil. \\ ${ }^{7}$ Departamento de Genética, Instituto de Ciências Biológicas, Universidade Federal do Amazonas, Avenida General Rodrigo \\ Otávio Jordão Ramos 6200, 69077-000, Manaus, AM, Brazil.
}

\begin{abstract}
Amphibians from Santa Isabel do Rio Negro, Brazilian Amazonia. A species list of amphibians from Santa Isabel do Rio Negro in Brazilian Amazonia is provided. Collections were made from March-April 2012 along each of two 3-km trails with the following sampling methods: (1) pitfall traps with drift fences; (2) visual and auditory surveys; and (3) chance encounters. The trail at Daraá is north of the Rio Negro, whereas the other in Ayuanã is south of the river. Forty species of anurans and one salamander species representing 20 genera and nine families were recorded. The species composition was compared with those of 16 other studies conducted in the Guiana, Imeri, and Jaú areas of endemism, where species richness varies from 21-63, and similarity indices range from 23-100\%. The anuran fauna at our sites resembles that of Flota Faro in eastern Amazonia more than it does that of the nearest site in the Departamento del Guainía of Colombia. The index of similarity is extremely variable between sites of the same and distinct areas of endemism. This pattern also was observed in the cluster analysis. As expected, geographically close areas have similar faunal compositions. However, the anuran fauna of
\end{abstract}


Parque Nacional do Jaú (Jaú area of endemism) resembles that of Manaus (Guiana area of endemism) more closely than it does that of the Ayuanã River, which belongs to the same area of endemism as Parque Nacional do Jaú. The limits of the areas of endemism are better defined by the presence / absence of other terrestrial vertebrates, such as birds and mammals, than by the assemblage of amphibians and squamate reptiles.

Keywords: Anura, areas of endemism, Caudata, similarity index, species richness, western Amazonia.

\begin{abstract}
Resumo
Anfíbios de Santa Isabel do Rio Negro, Amazônia Brasileira. No presente estudo fornecemos uma lista de espécies de anfíbios de Santa Isabel do Rio Negro na Amazônia Brasileira. As amostragens foram realizadas de março a abril de $2012 \mathrm{em}$ dois conjuntos de trilhas de $3 \mathrm{~km}$ de extensão, usando os seguintes métodos: (1) armadilhas de interceptação e queda com cerca direcionadora; (2) amostragens visuais e auditivas simultâneas; (3) encontros ocasionais. As trilhas foram instaladas ao norte (rio Daraá) e ao sul (rio Ayuanã) do rio Negro. Registramos 40 espécies de anuros e uma espécie de salamandra, pertencentes a 20 gêneros e nove famílias. A composição de espécies foi comparada com as de 16 outros estudos desenvolvidos nas áreas de endemismo Guiana, Imeri e Jaú, onde a riqueza de espécies variou de 21 a 63, e a similaridade, de 23 a 100\%. A anurofauna das duas áreas estudadas foi mais similar à de Flota Faro, localizada na Amazônia Oriental, do que à de um sítio mais próximo, Departamento del Guainía, Colômbia. O índice de similaridade foi extremamente variável entre os sítios da mesma ou de distintas áreas de endemismo. Esse padrão também foi observado nas análises de agrupamento. Como esperado, áreas geograficamente mais próximas foram mais similares na composição da anurofauna. No entanto, a anurofauna do Parque Nacional do Jaú (área de endemismo Jaú) foi mais similar à de Manaus (área de endemismo Guiana) do que à do rio Ayuanã, que pretence à mesma área de endemismo que o Parque Nacional do Jaú. Os limites das áreas de endemismo podem ser melhor definidos para outros vertebrados terrestres, como aves e mamíferos, do que para anfíbios e répteis Squamata.
\end{abstract}

Palavras-chave: Amazônia Ocidental, Anura, áreas de endemismo, Caudata, índice de similaridade, riqueza de espécies.

\section{Introduction}

The amphibian diversity of Amazonia is estimated to exceed 550 species (WWF 2010, Funk et al. 2012). However, some authors (Fouquet et al. 2007, Angulo and Reichle 2008, Funk et al. 2012) have suggested that undescribed cryptic diversity may increase this number markedly. Minimally 332 amphibian species occur in Amazonian Brazil; these include 309 anurans (Hoogmoed and Galatti 2017), five salamanders (Brcko et al. 2013, Hoogmoed 2016a), and 18 caecilians (Hoogmoed 2016b).

There are several inventories of amphibians from the northern (e.g., Hoogmoed and Ávila-
Pires 1991, Reynolds and MacCulloch 2012) and western Amazonian regions (e.g., Duellman 1978, 2005, Bernarde 2007). In contrast, less is known about amphibian assemblages in Amazonian Brazil. Although more reports have been published during the last decade (e.g., Bernarde 2007, Ávila-Pires et al. 2010, Ilha and Dixo 2010, Prudente et al. 2013), the amphibian inventories from Amazonian Brazil are scarce, fragmented, and frequently published in "gray" literature (fide Azevedo-Ramos and Galatti 2002). Published species inventories and field guides for Amazonian Brazil (e.g., Crump 1971, Ilha and Dixo 2010, Lima et al. 2012) traditionally are concentrated along the main 
tributaries of the Amazon River or the few regions that could be accessed by roads (Azevedo-Ramos and Galatti 2002). More recently, difficult-to-access areas have been inventoried (e.g., Lima 2008, Ávila-Pires et al. 2010). Based on the results of published and unpublished studies since 2002, Azevedo-Ramos and Galatti (2002) concluded that there are distinct assemblages of anurans in different localities in Amazonian Brazil. This information is crucial for the formulation of conservation strategies in this region, but the conservation statuses of amphibians in this biome have yet to be determined (Peloso 2010).

There are distinct areas of endemism separated by the major rivers in Amazonia (Cracraft 1985, Ron 2000, Silva et al. 2005, Borges and Silva 2012). Most are described on the basis of terrestrial vertebrates (e.g., birds and primates) and have played an important role in understanding the evolution of the Amazonian biota (Silva et al. 2005). In the only study involving anurans, Ron's (2000) results are coincident with the areas of endemism found for terrestrial vertebrates.

Anurans are sensitive to environmental degradation and considered to be among the most vulnerable vertebrate groups (Navas and Otani 2007). In Brazil, 41 anuran species (ca. $4 \%$ of Brazilian amphibians) are threatened with extinction (Ministério do Meio Ambiente 2014). However, basic data (e.g., distribution) for the species are lacking. Therefore, species inventories are critical to obtain information on distributions and to discover undescribed species-data indispensable to formulation of reasonable conservation measures (Verdade et al. 2012).

Herein, we provide a list of species of anurans and salamander from the region of Santa Isabel do Rio Negro in Amazonas, Brazil, based on collections by three different sampling methods. The observed species diversity is compared with those of other studies of lowland forests located in the Imeri, Jaú, and Guiana areas of endemism.

\section{Materials and Methods}

\section{Study site}

We conducted our study at two sites in the region of Santa Isabel do Rio Negro, Amazonas state, Brazil: (1) the right margin of the Rio Daraá $\left(0^{\circ} 23^{\prime} 57^{\prime \prime} \mathrm{S} ; 6^{\circ} 47^{\prime} 12^{\prime \prime} \mathrm{W}\right)$, and (2) the right

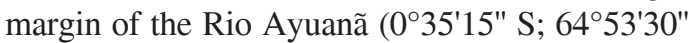
W) (Figure 1). Both rivers are black-water (as defined by Sioli 1991) tributaries of the Rio Negro. Situated in the Guiana area of endemism, the Rio Daraá is a left margin tributary has a highvelocity current and a complex of cataracts near its mouth; our collecting site is located at the base of the cataracts. Situated in the Imeri and Jaú areas of endemism, the Rio Ayuanã is a right margin tributary that has an almost imperceptible current. Along the edges of both rivers, we laid out a standardized grid composed of three, parallel 3-km-long trails, $1 \mathrm{~km}$ apart.

The region of Santa Isabel do Rio Negro is a tropical rainforest that lacks a dry season; precipitation in the driest month exceeds $60 \mathrm{~mm}$ (climate symbol "Af") according to the KöppenGeiger system (Peel et al. 2007). The annual mean air temperature is $27.5^{\circ} \mathrm{C}$ (range: 21.5 $32.6^{\circ} \mathrm{C}$ ). The rainiest season usually is between May and July, and the annual rainfall is 2800 mm.

\section{Data Collection}

We used three methods to sample amphibians between 28 March and 17 April 2012, as follow: (1) pitfall traps with drift fences; (2) visual and auditory surveys; and (3) chance encounters. The pitfall traps remained open for 20 days. Four trapping stations $500 \mathrm{~m}$ apart were set along each trail. Each array contained four bins $(\sim 100 \mathrm{~L} ; 51-\mathrm{cm}$ mouth diameter $\times 69 \mathrm{~cm}$ deep) in a Y-formation (Corn 1994, Cechin and Martins 2000, Ribeiro-Junior et al. 2008). The bins were separated by $10 \mathrm{~m}$ and linked by a polyethylene fence guide $(10 \mathrm{~m}$ long $\times 1 \mathrm{~m}$ high, with the bottom $0.10 \mathrm{~m}$ of the fence buried in the 


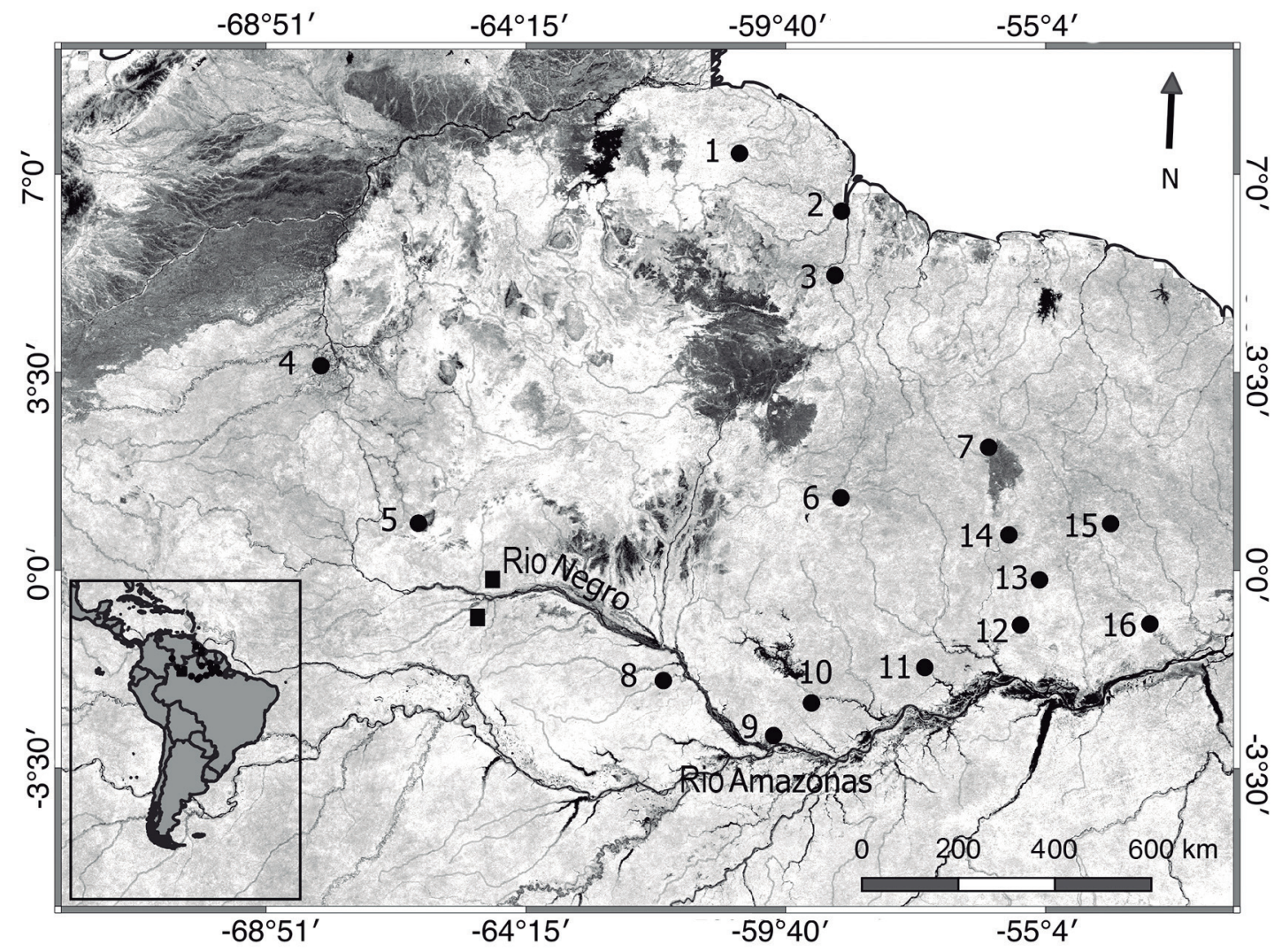

Figure 1. Geographic location of the study sites (Rio Daraá and Rio Ayuanã) in Santa Isabel do Rio Negro, Amazonas state, Brazil, and other sites used for comparisons. Squares: Rio Daraá (North) and Rio Ayuanã (South). Dots: 1. Baramita, Guyana; 2. Kartabo, Guyana; 3. Mabura, Guyana; 4. Comunidad La Ceiba, Departamento del Guainía, Colombia; 5. Cerro de la Neblina, Venezuela; 6. Estação Ecológica (ESEC) Grão-Pará North; 7. Sipaliwini, Suriname; 8. Parque Nacional do Jaú; 9. Manaus; 10. Rio Preto da Eva; 11. Floresta Estadual (FLOTA) Faro; 12. FLOTA Trombetas; 13. ESEC Grão-Pará South; 14. ESEC Grão-Pará Center; 15. Reserva Biológica Maicuru; 16. FLOTA Paru.

ground). Specimens were recovered from the buckets daily. Thus, a total of 24 stations of pitfall traps was checked each day to yield a total effort of 480 pitfall-days.

We sampled the nocturnal anuran assemblage by standardized and simultaneous visualencounter and auditory surveys (Crump and Scott Jr. 1994, Zimmerman 1994). These methods are complementary and adequate for surveying the distribution and abundance of anurans in long and short-term studies (Doan 2003). We sampled each trail 10 times between 18:30 and 22:00 h. Two observers stopped every $5 \mathrm{~m}$ and recorded the species in call activity and searched the litter and vegetation for anurans. Vocalizations were not recorded.

Amphibians also were collected by other researchers and assistants who were sampling other taxonomic groups on the same expedition (chance encounter method; Sawaya et al. 2008). 


\section{Species Identification and Preservation}

Species were identified based on their morphology based on the information provided by Duellman (1978, 2005) and Lima et al. (2012), or by their call based in the previous knowledge of the researchers along with the taxonomic expertise of the team. Only one species was identified exclusively by its vocalizations and no voucher was collected. The nomenclature in this study follows the classification of Amphibian Species of the World (Frost 2017). If we could not determine the identity of an individual anuran, we applied the follow conventions: confer (cf.) indicates that the determination is uncertain and specimen closely resembles the nominal; species (sp.) indicates that the individuals could not be related to any nominal species; affinis (aff.) indicates that the specimen is considered probably a new undescribed species (Bengtson 1988). Specimens were euthanized with an overdose of $2 \%$ lidocaine hydrochloride, and a muscle-tissue sample was removed from the thigh of each specimen. Tissue samples are deposited in the tissue collections at the Universidade Federal do Amazonas (CTGA-UFAM) and Instituto Nacional de Pesquisas da Amazônia (INPA). The voucher specimens were fixed in $10 \%$ formalin and later transferred to $70 \%$ alcohol. Vouchers were deposited in the Amphibians and Reptiles Collection of the INPA (INPA-H), Paulo Bürhnheim Zoological Collection of the Universidade Federal do Amazonas, Section Amphibians (CZPB-AA), and in the Herpetological Collection of the Universidade Regional do Cariri (URCA-H) (Appendix I). Collection of the material was authorized by the Instituto Chico Mendes de Conservação da Biodiversidade / SISBIO (\# 11323).

\section{Data Analysis}

There are many inventories of amphibian faunas in Amazonia. We compared our results with those of studies made (1) in the same area of endemism of our sampling sites (fide Ron 2000); (2) in unflooded, lowland forest (below $500 \mathrm{~m}$ a.s.1.); (3) at a comparable spatial scale to our study; (4) with taxonomic resolution (i.e., most of the frogs listed in the study are identified to species); and (5) using similar sampling methods and / or sampling effort. Reports with a complete list of species from a country were not considered. Given these criteria, the following published lists of other survey sites in the Guiana area of endemism were consulted: Suriname (Sipaliwini, Fouquet et al. 2015); Guyana (Baramita and Kartabo, Cole et al. 2013) (Mabura Hill, Ernst et al. 2005); Venezuela (Cerro de la Neblina, only lowland areas, Brewer-Carías 1988); Brazil (Rio Preto da Eva, Ilha and Dixo 2010) (Manaus, Tocher et al. 2001, Lima et al. 2012) [Floresta Estadual (FLOTA) Faro, FLOTA Trombetas, FLOTA Paru, Reserva Biológica (ReBio) Maicuru, Estação Ecológica Grão-Pará (sections North, Center and South), Ávila-Pires et al. 2010] and Jaú [Brazil: Parque Nacional do Jaú, NeckelOliveira and Gordo 2004]. In addition, we included studies from nearby areas for a better represention of the fauna of the Imeri area of endemism: Colombia (Comunidad La Ceiba, Departamento del Guainía, Lynch and VargasRamírez 2000, Lynch and Suárez-Mayorga 2011). Moreover, given the large ( $>1.7$ million $\mathrm{km}^{2}$, Silva et al. 2005) size of the Guiana area of endemism, the aforementioned sites are distributed across this region (i.e., Guiana, Suriname, Venezuela, and Brazil). The sampling techniques and sizes of study sites are not equivalent among the study sites.

To calculate faunal similarity, we used two indices: (1) Simpson's (1960) index is appropriate for incomplete sampling $\left[\left(\mathrm{C} / \mathrm{N}_{1}\right) \times\right.$ $100]$, where $C=$ the number of species found in common at both sites and $\mathrm{N}_{1}=$ the number of species at the most depauperate site or presumably, the most incompletely sampled site (Cole et al. 2013); (2) we also used the Jaccard similarity coefficient and the clustering method UPGMA (Primer software 6.0). We performed 
three cluster analyses using-(1) all the species found in all the areas; (2) only the identified species (i.e., excluding "sp.," “cf.," and "aff."; and (3) only the species identified and excluding typical diurnal species.

\section{Results}

A total of 41 species of amphibians (40 anurans; one salamander) was collected at both sites. These taxa represent 20 genera and nine families (Table 1; Figures 2, 3). In the Rio Daraá site, 33 species of anurans were recorded whereas in the Rio Ayuanã site, 30 species of anurans and one species of salamander were recorded. The number of species collected is correlated with the sampling methods. Thus, 34 species were found by visual encounter surveys (eight species only by this method), 28 species by chance encounters (two only by this method), and 17 species in pitfall traps (one species only by this method). In addition, five species were encountered auditory surveys, but only one was detected exclusively by this methodPhyllomedusa bicolor (Boddaert, 1772), which was not collected; the other four species were collected) (Table 1). Twenty-nine species were recovered with two or more sampling methods, and 23 species were collected at both sampling sites (i.e., Rio Daraá and Rio Ayuanã; Table 1). At a locality farther up the river, near the Rio Ayuanã site, additional anuran species not represented in this study were reported in fieldwork in 2013 by a team from the Museu Paraense Emílio Goeldi (Pará state). These are, as follow: Bufonidae: Amazophrynella minuta (Melin, 1941); Rhinella sp. (R. margaritifera Group); Hylidae: Boana boans (Linnaeus, 1758), Scinax garbei (Miranda-Ribeiro, 1926); and Phyllomedusidae: Phyllomedusa vaillantii Boulenger, 1882 (M.S. Hoogmoed pers. comm.).

Species richness values vary from $21-63$ in the studies conducted in the Guiana, Imeri, and Jaú areas of endemism (Table 2; Figure 1). The numbers of species shared range between 5 (among Rio Preto da Eva and FLOTA Paru and
ReBio Maicuru; Rio Daraá and ESEC Grão-Pará section North; Baramita and FLOTA Faro) and 29 (Parque Nacional do Jaú and Manaus; Table 2). Based on Simpson's index, the similarity of amphibian species among our sites and the other survey sites varies from $23-74 \%$ (Table 2). If all sites surveyed are included, the similarity value varies from 22\% (Rio Preto da Eva and FLOTA Paru and ReBio Maicuru) to $100 \%$ (Manaus and Rio Preto da Eva; Table 2).

The three cluster analyses reveal a similar pattern. The anuran faunas of the Rio Daraá and Rio Ayuanã sites resemble those of FOTA Faro in the Pará state, Brazil, more than those from the Departamento del Guainía in Colombia (Figure 4). In contrast, the species assemblages from the sites closer to ours (i.e., Manaus, Rio Preto da Eva, and Parque Nacional do Jaú in Brazil, and Cerro de la Neblina in Venezuela) were less similar than our sites, but they group with our study sites plus the FLOTA Faro site (Figure 4). As expected, geographically close sites (Figure 1) have similar anuran species compositions [Brazil, Pará state: FLOTA Trombetas, Estação Ecológica Grão-Pará (Center and South sections), ReBio Maicuru, FLOTA Paru; Guyana: Baramita, Kartabo; Brazil, Amazonas state: Manaus, Parque Nacional do Jaú, Rio Preto da Eva] (Figure 4).

\section{Discussion}

Visual encounter surveys were the most efficient method for sampling amphibians in our survey and also in studies conducted in forested areas elsewhere in the Amazonian Brazil (Neckel-Oliveira and Gordo 2004, Vogt et al. 2007, Menin et al. 2008, Turci and Bernarde 2008, Waldez et al. 2013). Although pitfall traps are considered useful for sampling herpetofaunas in tropical forests (Cechin and Martins 2000, Ribeiro-Júnior et al. 2008), the method is most effective for capturing squamates (Oliveira et al. 2014), or for use in biomes such as Cerrado and open areas in the Amazonia. In our study, pitfall traps yielded only one species of anuran that was not recovered by the other sampling methods. 
Table 1. Amphibian species recorded in the Santa Isabel do Rio Negro region, Amazonas state, Brazil. Sites of sampling: DR = Rio Daraá; AR = Rio Ayuanã. Sampling methods: AS = auditory survey; OE = occasional encounter; PT = pitfall traps with drift fence; VES = visual encounter survey.

\section{Order / Family / Species}

Sampling sites
DR AR Sampling methods

\section{ANURA}

\section{Aromobatidae}

Allobates femoralis (Boulenger, 1884)

Allobates paleovarzensis Lima, Caldwell, Biavati and Montanarin, 2010

Allobates sp.

\section{Bufonidae}

Rhaebo guttatus (Schneider, 1799)

Rhinella cf. margaritifera (Laurenti, 1768)

Rhinella marina (Linnaeus, 1758)
$X$

$\begin{array}{ccc} & X & \text { OE } \\ X & X & \text { PT, VES, OE } \\ X & & \text { VES, OE }\end{array}$

X

PT, OE

$X \quad X$

PT, OE, VES, AS

X $\quad X$

PT, VES

\section{Craugastoridae}

Pristimantis cf. ockendeni (Boulenger, 1912)

Pristimantis zeuctotylus (Lynch and Hoogmoed, 1977)

\section{Hylidae}

Boana cf. cinerascens (Spix, 1824)

Boana cf. geographica (Spix, 1824)

Boana wavrini (Parker, 1936)

Dendropsophus minusculus (Rivero, 1971)

Dendropsophus cf. minutus (Peters, 1872)

Dendropsophus parviceps (Boulenger, 1882)

Dendropsophus sarayacuensis (Shreve, 1935)

Osteocephalus leprieurii (Duméril and Bibron, 1841)

Osteocephalus oophagus Jungfer and Schiesari, 1995

Osteocephalus planiceps Cope, 1874

Osteocephalus taurinus Steindachner, 1862

Osteocephalus vilarsi (Melin, 1941)

Scinax sp. 1
X

$X$

$X$

VES, OE

VES

$\begin{array}{ccc}X & X & \text { VES, OE } \\ X & X & \text { VES, OE } \\ X & X & \text { VES, OE } \\ X & & \text { PT, VES } \\ X & X & \text { VES, OE, AS } \\ X & X & \text { VES, OE, AS } \\ & X & \text { VES } \\ X & X & \text { VES, OE } \\ X & X & \text { VES } \\ x & X & \text { VES, OE } \\ X & X & \text { VES, OE } \\ X & & \text { VES }\end{array}$


Table 1. Continued.

\begin{tabular}{|c|c|c|c|}
\hline \multirow{2}{*}{ Order / Family / Species } & \multicolumn{2}{|c|}{ Sampling sites } & \multirow{2}{*}{ Sampling methods } \\
\hline & DR & AR & \\
\hline Scinax sp. 2 & & $x$ & VES, OE \\
\hline Trachycephalus coriaceus (Peters, 1867) & $x$ & & VES \\
\hline $\begin{array}{l}\text { Trachycephalus cunauaru Gordo, Toledo, Suárez, } \\
\text { Kawashita-Ribeiro, Ávila, Morais and Nunes, } 2013\end{array}$ & $x$ & & VES, OE, AS \\
\hline \multicolumn{4}{|l|}{ Leptodactylidae } \\
\hline Adenomera andreae (Müller, 1923) & $x$ & $x$ & PT, VES, OE \\
\hline Leptodactylus knudseni Heyer, 1972 & $\mathrm{X}$ & $x$ & PT, VES, OE \\
\hline Leptodactylus mystaceus (Spix, 1824) & $x$ & $x$ & PT, VES, OE \\
\hline Leptodactylus pentadactylus (Laurenti, 1768) & $x$ & $x$ & PT, VES, OE \\
\hline Leptodactylus petersii (Steindachner, 1864) & $X$ & $x$ & $\mathrm{PT}, \mathrm{OE}$ \\
\hline Leptodactylus rhodomystax Boulenger, 1884 & $x$ & $x$ & PT, VES, OE \\
\hline Leptodactylus riveroi Heyer and Pyburn, 1983 & $X$ & $x$ & $\mathrm{PT}, \mathrm{OE}$ \\
\hline Lithodytes lineatus (Schneider, 1799) & & $x$ & PT \\
\hline Physalaemus ephippifer (Steindachner, 1864) & $X$ & & PT, VES \\
\hline \multicolumn{4}{|l|}{ Microhylidae } \\
\hline Adelastes hylonomos Zweifel, 1986 & $x$ & & VES \\
\hline Chiasmocleis hudsoni Parker, 1940 & $X$ & & PT, VES, OE \\
\hline Chiasmocleis ventrimaculata (Andersson, 1945) & & $x$ & PT, VES, OE \\
\hline Ctenophryne geayi Mocquard, 1904 & $x$ & $x$ & $\mathrm{PT}, \mathrm{VES}, \mathrm{OE}$ \\
\hline \multicolumn{4}{|l|}{ Phyllomedusidae } \\
\hline Callimedusa tomopterna (Cope, 1868) & $X$ & $X$ & VES, OE \\
\hline Phyllomedusa bicolor (Boddaert, 1772) & $X$ & & AS \\
\hline \multicolumn{4}{|l|}{ Pipidae } \\
\hline Pipa pipa (Linnaeus, 1758) & $x$ & $x$ & $\mathrm{OE}$ \\
\hline \multicolumn{4}{|l|}{ CAUDATA } \\
\hline \multicolumn{4}{|l|}{ Plethodontidae } \\
\hline Bolitoglossa sp. & & $x$ & VES \\
\hline Total number of species & 33 & 31 & \\
\hline
\end{tabular}



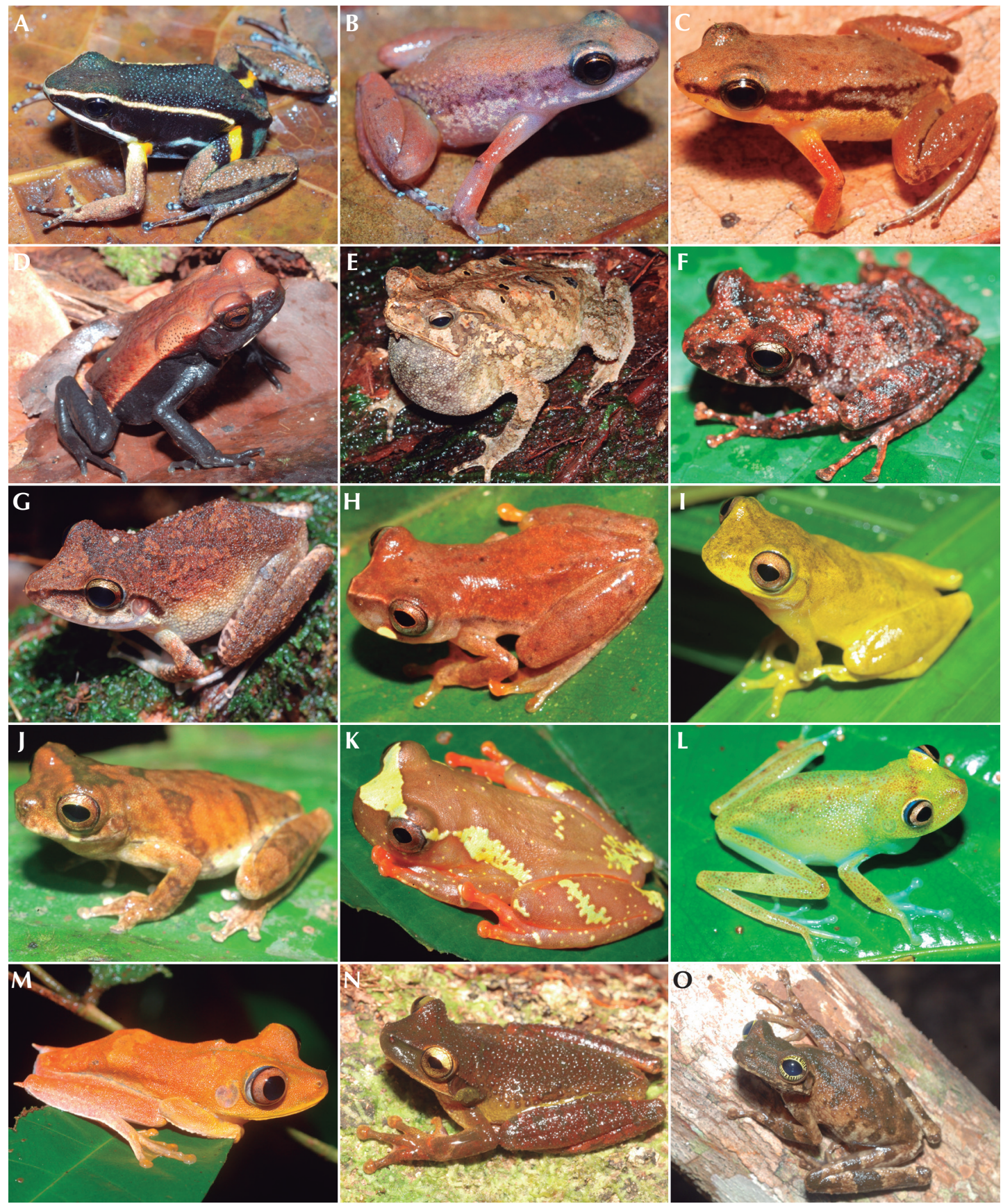

Figure 2. Amphibians found in the Santa Isabel do Rio Negro region, Amazonas state, Brazil: (A) Allobates femoralis; (B) Allobates paleovarzensis; (C) Allobates sp.; (D) Rhaebo guttatus; (E) Rhinella cf. margaritifera; (F) Pristimantis cf. ockendeni; (G) Pristimantis zeuctotylus; (H) Dendropsophus minusculus; (I) Dendropsophus cf. minutus; (J) Dendropsophus parviceps; (K) Dendropsophus sarayacuensis; (L) Boana cf. cinerascens; (M) Boana cf. geographica; (N) Osteocephalus leprieurii; (O) Osteocephalus oophagus (Photos by VTC). 


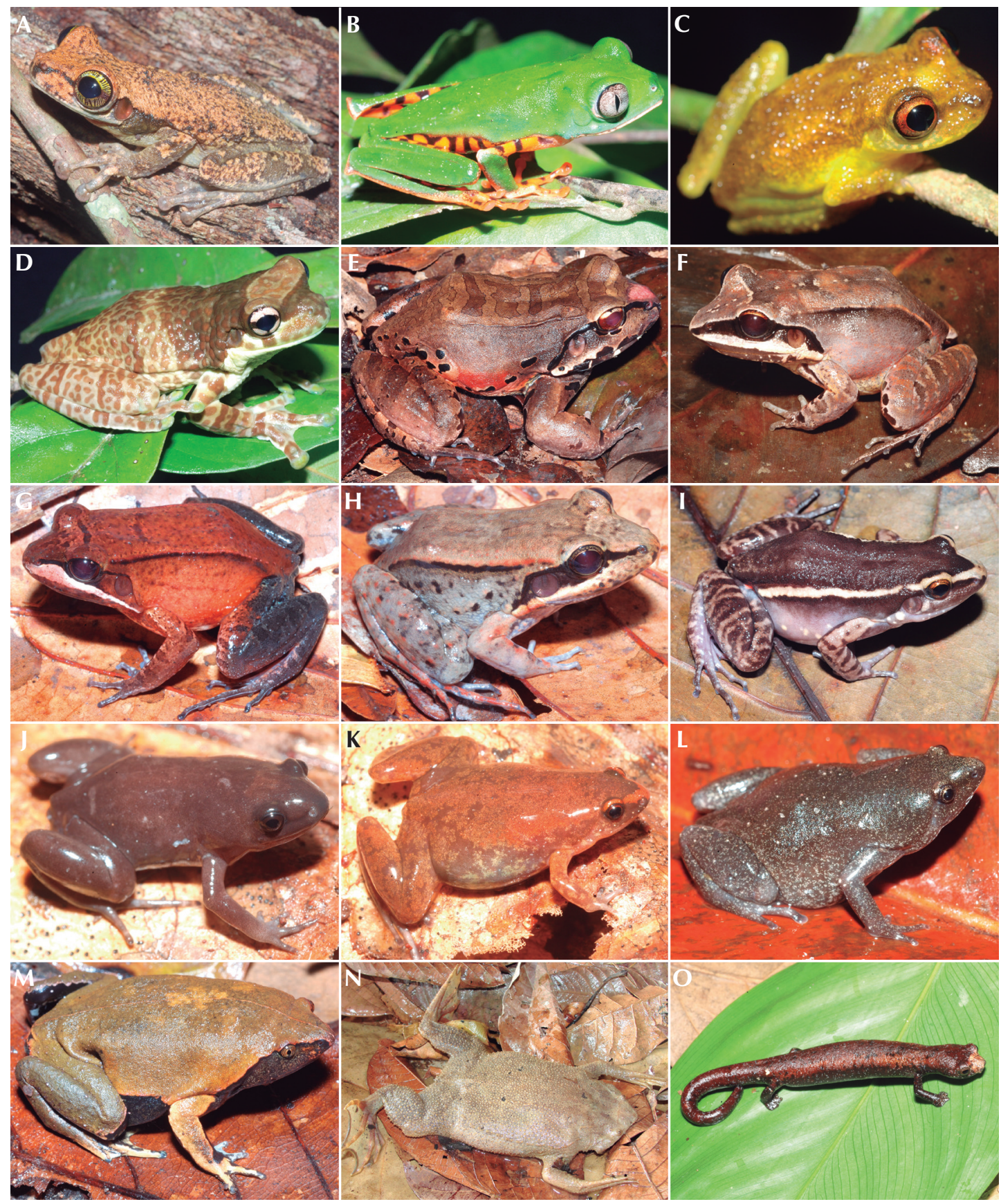

Figure 3. Amphibians found in the Santa Isabel do Rio Negro region, Amazonas state, Brazil: (A) Osteocephalus taurinus; (B) Callimedusa tomopterna; (C) Scinax sp. 1; (D) Trahycephalus cunauaru; (E) Leptodactylus knudseni; (F) Leptodactylus mystaceus; (G) Leptodactylus rhodomystax; (H) Leptodactylus riveroi; (I) Lithodytes lineatus; (J) Adelastes hylonomos; (K) Chiasmocleis hudsoni; (L) Chiasmocleis ventrimaculata; (M) Ctenophryne geayi; (N) Pipa pipa; (O) Bolitoglossa sp. (Photos A-I and K-O by VTC; photo J by M. Gordo.) 


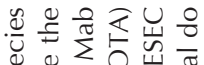

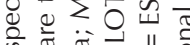

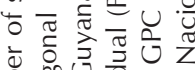

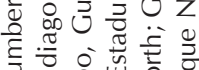

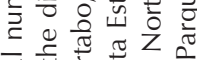

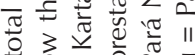

o

至苛

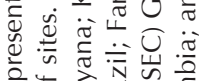

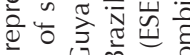

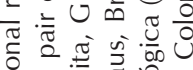

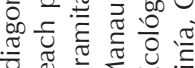

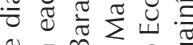

Æ

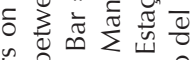

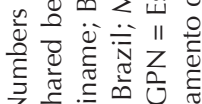

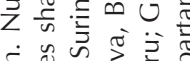

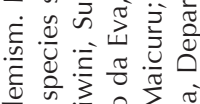

过

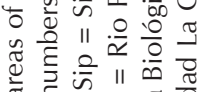

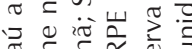

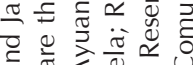

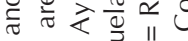

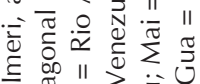

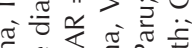

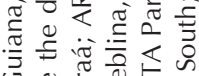

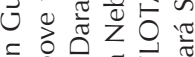

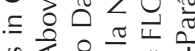

要金

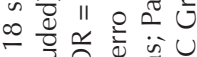

.

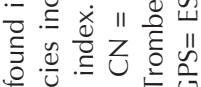

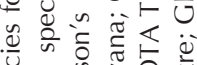

के

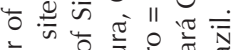

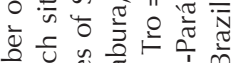

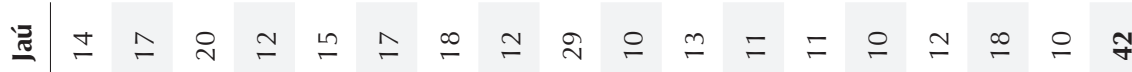

J్

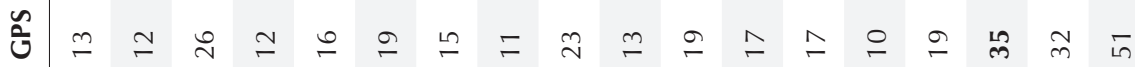

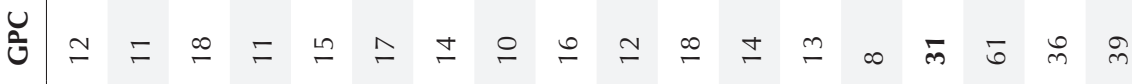

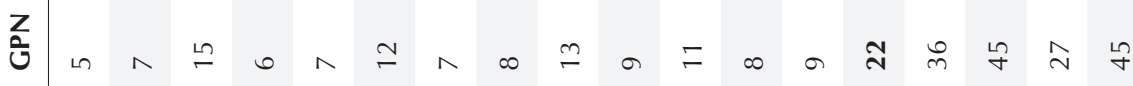

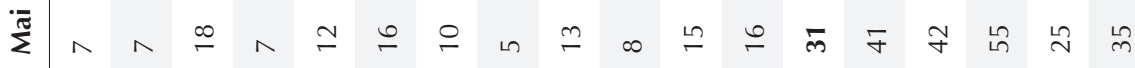

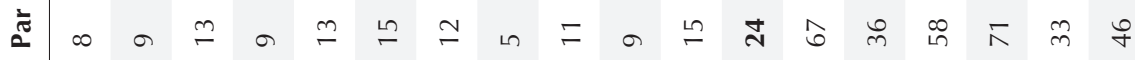

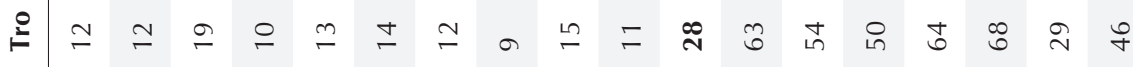

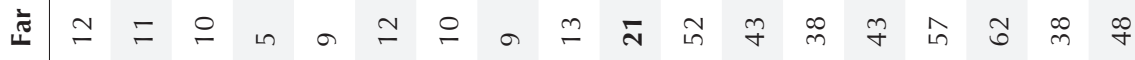

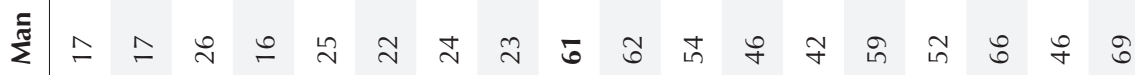

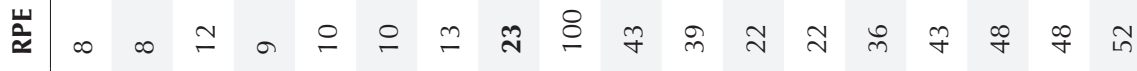

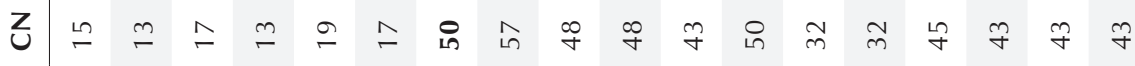

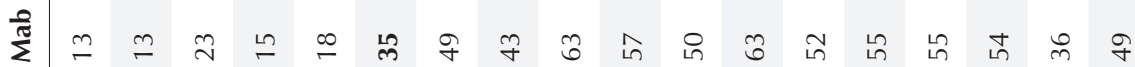

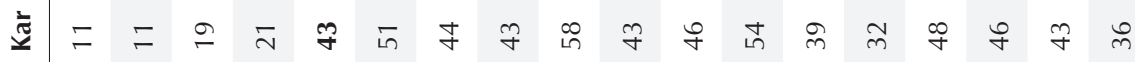

๓

ஸे

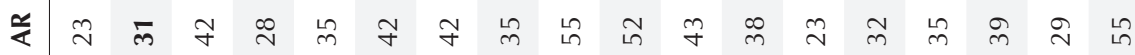

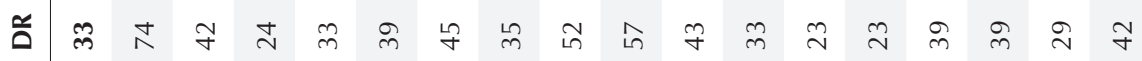

造

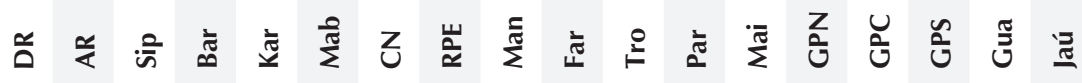


The abundance of species of Hylidae and Leptodactylidae is typical of studies from other different regions of Amazonia (Gordo 2003, Neckel-Oliveira and Gordo 2004, Ilha and Dixo 2010, Lima et al. 2012, Waldez et al. 2013) and other biomes in South America (Duellman 1988). The numbers of anurans and salamander species that we report represent about $13 \%$ of the total number of species known to occur in Amazonian Brazil (Hoogmoed 2016a, Hoogmoed and Galatti 2017). Given the great diversity of cryptic anuran species in Amazonia revealed by molecular evidence (SISBIOTA project, unpubl. data), it is possible that undescribed species may be represented in our samples.

The species of Bolitoglossa that we found probably is undescribed. This is the first record of a salamander north of the Rio Solimões. Our data corroborate the suggestion of Brcko et al. (2013) that the distribution of Bolitoglossa includes the western and southern parts of the Guiana Region and the conclusion that the genus is not restricted to the area south of the Rio Amazonas. The rare microhylid anuran Adelastes hylonomus Zweifel, 1986, has been recorded recently in our study area; this is the first record of this species outside Venezuela (Almeida et al. 2014).

Our study was located in two areas of endemism: Guiana (Rio Daraá) and Imeri / Jaú (Rio Ayuanã) (Silva et al. 2005, Borges and Silva 2012). The lower part of Imeri area has been called Jaú, but the geographical limits of this area are uncertain (Borges and Silva 2012). There are many species inventories for the Guiana area of endemism as a result of surveys in Guyana, Suriname, and French Guiana (e.g., Hoogmoed and Ávila-Pires 1991, MacCulloch and Reynolds 2012, Reynolds and MacCulloch 2012). In addition, Molina et al. (2009) provided a complete list of species occurring Venezuela and Lescure and Marty (2000) in French Guiana. However, the amphibian assemblages reported in these studies cannot be directly compared to the results of our study because anurans were sampled in highland areas (MacCulloch and

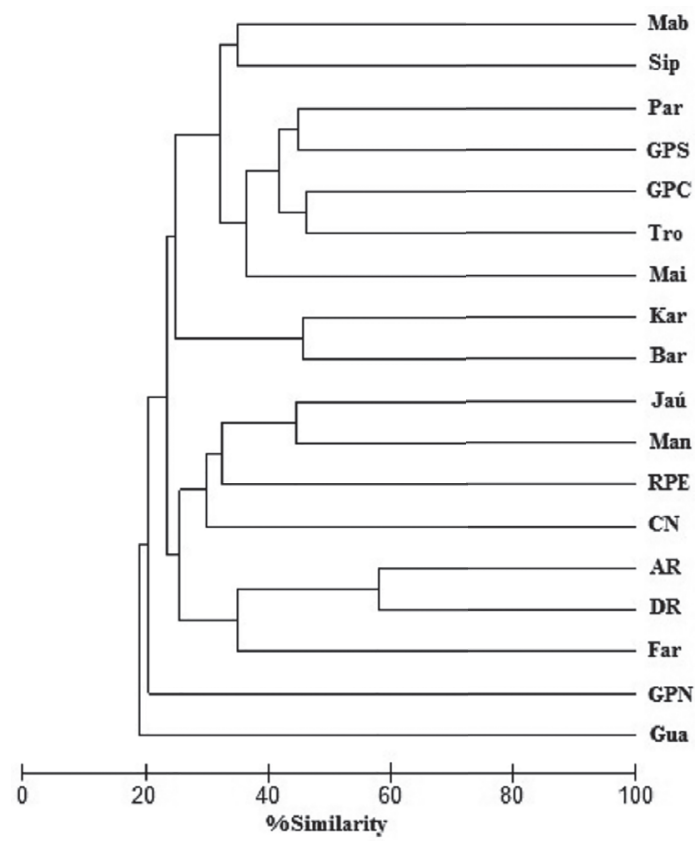

Figure 4. Dendrogram for the coefficient of Jaccard and UPGMA cluster analysis of 18 amphibian assemblages from lowland Amazonia forests. The cluster analyses were performed using only the species identified (excluding "sp.," "cf.," and "aff."). Abbreviations of the site names as in Table 2.

Reynolds 2012) and in disturbed forest areas during the dry season (Reynolds and MacCulloch 2012) or over greater spatial scales (Lescure and Marty 2000, Molina et al. 2009). Species inventories in the Imeri and Jaú areas of endemism are scarce and include studies conducted in the Departamento del Guainía in Colombia, the Colombian lowlands east of the Andes (Lynch and Vargas-Ramírez 2000, Lynch and Suárez-Mayorga 2011), and the Parque Nacional do Jaú (Neckel-Oliveira and Gordo 2004), respectively. Some species descriptions and incomplete species lists emerged from expeditions in the first half of the $20^{\text {th }}$ century in areas near our study sites [São Gabriel da Cachoeira, Uaupés, Cucuí (Guiana area of endemism) and Taracuá / Marabitana / Pari / 
Iauaretê (Imeri area of endemism); Melin 1941, Lutz and Kloss 1952] but they cannot be compared with our results in detail.

Study sites located relatively near our sites share more species in common with our sites: Manaus (17 species at both Rio Daraá and Rio Ayuanã; indices 52 and 55\%, respectively) and Parque Nacional do Jaú (17 species at Rio Ayuanã; index 55\%) (Table 2, Figure 1). The sites located in Manaus were studied during the 1990s and later (Zimmerman and Rodrigues 1990, Lima et al. 2012). In contrast, at more distant sampling sites, (e.g., sites in Pará state), the similarity varies from 23\% (Rio Ayuanã and ReBio Maicuru; Rio Daraá and ReBio Maicuru and Estação Ecológica Grão-Pará section North) to $57 \%$ (Rio Daraá and FLOTA Faro). Comparing all pairs of sites, the highest Simpson's index (100\%) occurs between the closest geographically sites such as Manaus and Rio Preto da Eva. The closest site to ours is Cerro de la Neblina, which shares 15 species (45\%) and 13 species (42\%) with the Rio Daraá and Rio Ayuanã sites, respectively.

The index of similarity is extremely variable between sites of the same and distinct areas of endemism-a pattern that also characterizes the cluster analysis and reflects contradictions. As anticipated, geographically close areas have similar anuran faunas (Figure 4). Therefore, the similarity among our study sites and those from the Departamento del Guainía in Colombia are low because they belong to different area of endemism (Rio Daraá: Guiana; Rio Ayuanã: Imeri/Jaú; Guainía, Colombia: Imeri). However, the anuran assemblage of Parque Nacional do Jaú (Jaú area of endemism) is more similar to that of Manaus (Guiana area of endemism) than to the Rio Ayuanã, which belongs to the same area of endemism as Jaú. With respect to lizards, Ávila-Pires et al. (2009) recognized only Napo, Inambari, and Guiana areas of endemism, finding little or no evidence of other areas of endemism. The limits of the areas of endemism are better defined by other terrestrial vertebrates (birds and mammals) than amphibians and perhaps squamate reptiles, and in the case of the Jaú area of endemism, the geographical limits can be defined only partially (Borges and Silva 2012).

The differences in species richness, number of species shared, and the faunal similarities among the Amazonian sites may reflect differences in sampling efforts, the season during which sampling was conducted (Azevedo-Ramos and Galatti 2002), the total area sampled (e.g., Ilha and Dixo 2010), and the sampling methods employed (e.g., doubleended funnel traps with drift fences; Waldez et al. 2013). Each of the latter directly affects the numbers of individuals and species collected; thus, the observed species richness may be artificial. Differences in habitat also affect faunal composition (e.g., Cole et al. 2013 on the herpetofauna of Guyana); highland areas, savannas, and lowland forest sites in Amazonia have distinct faunas (Duellman 1999).

\section{Acknowledgments}

We thank Ocírio Pereira, Sebastião Batista, and local residents for assistance with fieldwork. Maria Isabel da Silva reviewed the English usage of the manuscript for us, and Sérgio H. Borges assisted us with the cluster analysis and dicussion about Amazonian biogeography. Financial support was provided by the SISBIOTA Program: Ministério da Ciência, Tecnologia, Inovações e Comunicações, Conselho Nacional de Desenvolvimento Científico e TecnológicoCNPq (\# 563348/2010) and Fundação de Amparo à Pesquisa do Estado do AmazonasFAPEAM (Edital FAPEAM / SISBIOTA). Marinus S. Hoogmoed, Vanessa K. Verdade, and anonymous reviewers provided valuable suggestions on an earlier draft of this manuscript. Marinus S. Hoogmoed kindly provided data from four other species found near to our study sites. This study was supported by fellowships from FAPEAM to APA, Coordenação de Aperfeiçoamento de Pessoal de Nível SuperiorCAPES to DPO, and research productivity grants from $\mathrm{CNPq}$ to $\mathrm{MM}$ and $\mathrm{TH}$. 


\section{References}

Almeida, A. P., V. T. Carvalho, M. Gordo, R. R. Zamora, and M. Menin. 2014. First record of Adelastes hylonomos Zweifel, 1986 (Amphibia, Anura, Microhylidae) outside the type locality, with notes on the advertisement call. Ckeck List 10: 1226-1228.

Angulo, A. and S. Reichle. 2008. Acoustic signals, species diagnosis, and species concepts: the case of a new cryptic species of Leptodactylus (Amphibia, Anura, Leptodactylidae) from the Chapare region, Bolivia. Zoological Journal of the Linnean Society 152: 59-77.

Ávila-Pires, T. C. S., M. S. Hoogmoed, and W. A. Rocha. 2010. Notes on the Vertebrates of northern Pará, Brazil: a forgotten part of the Guianan Region, I. Herpetofauna. Boletim do Museu Paraense Emílio Goeldi, Ciências Naturais 5: 13-112.

Ávila-Pires, T. C. S., L. J. Vitt, S. S. Sartorius, and P. A. Zani. 2009. Squamata (Reptilia) from four sites in southern Amazonia, with a biogeographic analysis of Amazonian lizards. Boletim do Museu Paraense Emílio Goeldi, Ciências Naturais 4: 99-118.

Azevedo-Ramos, C. and U. Galatti. 2002. Patterns of amphibian diversity in Brazilian Amazonia: conservation implications. Biological Conservation 103: 103-111.

Bengtson, P. 1988. Open nomenclature. Palaeontology 31: $223-227$.

Bernarde, P. S. 2007. Ambientes e temporada de vocalização da anurofauna no município de Espigão do Oeste, Rondônia, Sudoeste da Amazônia, Brasil (Amphibia: Anura). Biota Neotropica 7: 87-92.

Borges, S. H. and J. M. C. Silva. 2012. A new area of endemism for Amazonia birds in the Rio Negro basin. Wilson Journal of Ornithology 124: 15-23.

Brcko, I. C., M. S. Hoogmoed, and S. Neckel-Oliveira. 2013. Taxonomy and distribution of the salamander genus Bolitoglossa Duméril, Bibron \& Duméril, 1854 (Amphibia, Caudata, Plethodontidae) in Brazilian Amazonia. Zootaxa 3686: 401-431.

Brewer-Carías, C. 1988. Cerro de la Neblina: Resultados de la Expedición 1983-1987. Caracas. Fundación para el Desarrollo de las Ciencias Físicas, Matematias y Naturales. 922 pp.

Cracraft, J. 1985. Historical biogeography and patterns of differentiation within the South American avifauna: areas of endemism. Ornithological Monographs 36: 49-84.
Cechin, S. Z. and M. Martins. 2000. Eficiência de armadilhas de queda (pitfall traps) em amostragem de anfíbios e répteis no Brasil. Revista Brasileira de Zoologia 17: 729-740.

Cole, C. J, C. R. Townsend, R. P. Reynolds, R. D. MacCulloch, and A. Lathrop. 2013. Amphibians and reptiles of Guyana, South America: illustrated keys, annotated species accounts, and a biogeographic synopsis. Proceedings of the Biological Society of Washington 125: 317-578.

Corn, P. S. 1994. Standard techniques for inventory and monitoring: straight-line drift fences and pitfall traps. Pp. 109-117 in W. R. Heyer, M. A. Donnelly, R. W. McDiarmid, L.-A. C. Hayek, and M. S. Foster (eds.), Measuring and Monitoring Biological Diversity: Standard Methods for Amphibians. Washington. Smithsonian Institution Press.

Crump, M. L. 1971. Quantitative analysis of the ecological distribution of a tropical herpetofauna. Occasional Papers of the Museum of Natural History of the University of Kansas 3: 1-62.

Crump, M. L. and N. J. Scott Jr. 1994. Visual encounter surveys. Pp. 84-92 in W. R. Heyer, M. A. Donnelly, R. W. McDiarmid, L.-A. C. Hayek, and M. S. Foster (eds.), Measuring and Monitoring Biological Diversity: Standard Methods for Amphibians. Washington. Smithsonian Institution Press.

Doan, T. M. 2003. Which methods are most effective for surveying rain forest herpetofauna? Journal of Herpetology 37: 72-81.

Duellman, W. E. 1978. The biology of an Equatorial herpetofauna in Amazonia Ecuador. University of Kansas Museum of Natural History, Miscellaneous Publication 65: 1-352.

Duellman, W. E. 1988. Pattern of species diversity in anuran amphibians in the American tropics. Annals of the Missouri Botanical Garden 75: 79-104.

Duellman, W. E. 1999. Distribution patterns of amphibians in South America. Pp. 255-328 in W. E. Duellman (ed.), Patterns of Distribution of Amphibians: A Global Perspective. Baltimore. Johns Hopkins University Press.

Duellman, W. E. 2005. Cusco Amazónico: the Lives of Amphibians and Reptiles in an Amazonia Rainforest. Ithaca. Cornell University Press. 488 pp.

Ernst, R., M.-O. Rödel, and D. Arjoon. 2005. On the cutting edge. The anuran fauna of the Mabura Hill Forest Reserve, Central Guyana. Salamandra 41: 179-194.

Fouquet, A., A. Gilles, M. Vences, C. Marty, M. Blanc, and N. Gemmell. 2007. Underestimation of species richness 
in Neotropical frogs suggested by phylogenetic and distance-based analysis of mtDNA. PLOS ONE 2: e1109.

Fouquet, A., J.-P. Vacher, V. Kadosoe, R. Jairam, and P. E. Ouboter. 2015. Checklist of the amphibians of the Sipaliwini area, Suriname. Herpetology Notes 8: 63-68.

Frost, D. R. 2017. Amphibian Species of the World: an Online Reference. Version 6.0. Electronic Database accessible at http://research.amnh.org/herpetology/ amphibia/index.html. American Museum of Natural History, New York, USA. Captured on 09 July 2017.

Funk, W. C., M. Caminer, and S. R. Ron. 2012. High levels of cryptic species diversity uncovered in Amazonia frogs. Proceedings of the Royal Society of London B 279: 1806-1814.

Gordo, M. 2003. Os anfíbios anuros do Baixo Rio Purus/ Solimões. Pp. 243-256 in C. P. Deus, R. Silveira, and L. H. R. Py-Daniel (eds.), Piagaçu-Purus: Bases Científicas para a Criação de uma Reserva de Desenvolvimento Sustentável. Manaus. Instituto de Desenvolvimento Sustentável Mamirauá.

Hoogmoed, M. S. 2016a. Censo da Biodiversidade da Amazônia Brasileira. Grupo: Caudata. Electronic Database accessible at http://www.museu-goeldi.br/ censo/ Museu Paraense Emilio Goeldi, Belém. Captured on 19 December 2016.

Hoogmoed, M. S. 2016b. Censo da Biodiversidade da Amazônia Brasileira. Grupo: Gymnophiona (25 July 2016). Electronic Database accessible at http://www. museu-goeldi.br/censo/ Museu Paraense Emilio Goeldi, Belém. Captured on 19 December 2016.

Hoogmoed, M. S. and T. C. S. Ávila-Pires. 1991. Annotated checklist of the herpetofauna of Petit Saut, Sinnamary River, French Guiana. Zoologische Mededelingen 65: $53-88$.

Hoogmoed, M. S. and U. Galatti, 2017. Censo da Biodiversidade da Amazônia Brasileira. Grupo: Anura (30 March 2017). Electronic Database accessible at http://www.museu-goeldi.br/censo/ Museu Paraense Emilio Goeldi, Belém. Captured on 09 July 2017.

Ilha, P. and M. Dixo. 2010. Anurans and lizards, Rio Preto da Eva, Amazonas, Brazil. Check List 6: 17-21.

Lescure, J. and C. Marty. 2000. Atlas des Amphibiens de Guyane. Patrimoines Naturels 45: 1-388.

Lima, A. P., W. E. Magnusson, M. Menin, L. K. Erdtmann, D. J. Rodrigues, C. Keller, and W. Hödl. 2012. Guia de Sapos da Reserva Adolpho Ducke, Amazônia Central. $2^{\text {nd }}$ Edition. Manaus. Instituto Nacional de Pesquisas da Amazônia. 187 pp.
Lima, J. D. 2008. A herpetofauna do Parque Nacional Montanhas do Tumucumaque, Amapá, Brasil, Expedições I a V. Pp. 38-50 in E. Bernard (ed.), Inventários Biológicos Rápidos no Parque Nacional Montanhas do Tumucumaque, Amapá, Brasil. RAP Bulletin of Biological Assessment 48. Arlington. Conservation International.

Lutz, B. and G. R. Kloss. 1952. Anfíbios anuros do alto Solimões e Rio Negro. Apontamentos sôbre algumas formas e suas vicariantes. Memórias do Instituto Oswaldo Cruz 50: 624-678.

Lynch, J. D. and M. A. Vargas-Ramírez. 2000. Lista preliminar de especies de anuros del Departamento del Guainía, Colombia. Revista de la Academia Colombiana de Ciencias 24: 579-589.

Lynch, J. D. and A. M. Suárez-Mayorga. 2011. Clave ilustrada de los renacuajos en las tierras bajas al oriente de los Andes, con énfasis em Hylidae. Caldasia 33: $235-270$.

MacCulloch, R. D. and R. P. Reynolds. 2012. Amphibians and reptiles from Paramakatoi and Kato, Guyana. Check List 8: 207-210.

Melin, D. 1941. Contributions to the knowledge of the Amphibia of South America. Meddelanden frän Göteborgs Musei Zoologiska Avdelning 88, Sjatte Foljden, Ser. B 1: 1-71.

Menin M., F. Waldez, and A. P. Lima. 2008. Temporal variation in the abundance and number of species of frogs in 10,000 ha of a forest in Central Amazonia, Brazil. South American Journal of Herpetology 3: 6881.

Ministério do Meio Ambiente. 2014. Portaria No. 444 de 17 de dezembro de 2014. Lista Nacional Oficial de Espécies da Fauna Ameaçadas de Extinção. Diário Oficial da União, Seção 1, 245: 121-126.

Molina, C., J. C. Señaris, M. Lampo, and A. Ryal. 2009. Anfibios de Venezuela: Estado del Conocimiento y Recomendaciones para su Conservación. Caracas. Conservación Internacional Venezuela, Instituto de Zoología y Ecología Tropical, Fundación La Salle de Ciencias Naturales, Instituto Venezolano de Investigaciones Científicas, Gold Reserves Inc. 130 pp.

Navas, C. A. and L. Otani. 2007. Physiology, environmental change, and anuran conservation. Phyllomedusa 6: 83103.

Neckel-Oliveira, S. and M. Gordo. 2004. Anfíbios, lagartos e serpentes do Parque Nacional do Jaú. Pp. 161-176 in S. H. Borges, S. Iwanaga, C. C. Durigan, and M. R. Pinheiro (eds.), Janelas para a Biodiversidade no 
Parque Nacional do Jaú, uma Estratégia para o Estudo da Biodiversidade na Amazônia. Manaus. Fundação Vitória Amazônica.

Oliveira, D. P., S. M. Souza, L. Frazão, A. P. Almeida, and T. Hrbek. 2014. Lizards from central Jatapú River, Amazonas, Brazil. Check List 10: 46-53.

Peel, M. C., B. L. Finlayson, and T. A. McMahon. 2007. Updated world map of the Köppen-Geiger climate classification. Hydrology and Earth System Sciences 11: 1633-1644.

Peloso, P. L. V. 2010. A safe place for amphibians? A cautionary tale on the taxonomy and conservation of frogs, caecilians, and salamanders in the Brazilian Amazonia. Zoologia 27: 667-673.

Prudente, A. L. C., M. J. Sturaro, A. E. M. Travassos, G. F. Maschio, and M. C. Santos-Costa. 2013. Anurans of the Urucu Petrol Basin, municipality of Coari, state of Amazonas, northern Brazil. Check List 9: 601-606.

Reynolds, R. P. and R. D. MacCulloch. 2012. Preliminary checklist of amphibians and reptiles from Baramita, Guyana. Check List 8: 211-214.

Ribeiro-Júnior, M. A., T. A. Gardner, and T. C. S. ÁvilaPires. 2008. Evaluating the effectiveness of herpetofaunal sampling techniques across a gradient of habitat change in a tropical forest landscape. Journal of Herpetology 42: $733-749$

Ron, S. R. 2000. Biogeographic area relationships of lowland Neotropical rainforest based on raw distributions of vertebrate groups. Biological Journal of the Linnean Society 71: 379-402.

Sawaya, R. J., O. A. Marques, and M. Martins. 2008. Composição e história natural das serpentes de Cerrado de Itirapina, São Paulo, sudeste do Brasil. Biota Neotropica 8: 127-149.

Silva, J. M. C., A. B. Rylands, and G. A. B. da Fonseca. 2005. O destino das áreas de endemismo da Amazônia. Megadiversidade 1: 124-131.

Simpson, G. G. 1960. Notes on the measurement of faunal resemblance. American Journal of Science 258: 300 311.
Sioli, H. 1991. Amazônia: Fundamentos da Ecologia da Maior Região de Florestas Tropicais. Petrópolis. Editora Vozes. 72 pp.

Tocher, M. D., C. Gascon, and J. Mayer. 2001. Community composition and breeding success of Amazonia frogs in continuous forest and matrix habitat aquatic sites. Pp. 235-247 in R. O. Bierregaard Jr, C. Gascon, T. E. Lovejoy, and R. Mesquita (eds.), Lessons from Amazonia: The Ecology and Conservation of a Fragmented Forest. New Haven. Yale University Press.

Turci, L. C. B. and P. S. Bernarde. 2008. Levantamento herpetofaunístico em uma localidade no município de Cacoal, Rondônia, Brasil. Bioikos 22: 101-108.

Verdade, V. K., P. H. Valdujo, A. C. Carnaval, L. Schiesari, L. F. Toledo, T. Mott, G. V. Andrade, P. C. Eterovick, M. Menin, B. V. S. Pimenta, C. Nogueira, C. S. Lisboa, C. D. Paula, and D. L. Silvano. 2012. A leap further: the Brazilian Amphibian Conservation Action Plan. Alytes 29: $28-42$.

Vogt, R. C., C. R. Ferrara, R. Bernhard, V. T. Carvalho, D. C. Balensiefer, L. Bonora, and S. M. H. Novele. 2007. Herpetofauna. Pp. 127-143 in L. R. Py-Daniel, C. P. Deus, A. L. Henriques, D. M. Pimpão, and O. M. Ribeiro (orgs.), Biodiversidade do Médio Madeira: Bases Científicas para Propostas de Conservação. Manaus. Instituto Nacional de Pesquisas da Amazônia.

Waldez, F., M. Menin, and R. C. Vogt. 2013. Diversidade de anfíbios e répteis Squamata na região do baixo rio Purus, Amazônia Central, Brasil. Biota Neotropica 13: 300316.

WWF. 2010. Amazon Alive! A Decade of Discovery 19992009. Godalming. World Wildlife Fund. 57 pp.

Zimmerman, B. L. 1994. Audio strip transects. Pp. 92-97 in W. R. Heyer, M. A. Donnelly, R. W. McDiarmid, L.-A. C. Hayek, and M. S. Foster (eds.), Measuring and Monitoring Biological Diversity: Standard Methods for Amphibians. Washington. Smithsonian Institution Press.

Zimmerman, B. L. and M. T. Rodrigues. 1990. Frogs, snakes, and lizards or the INPA-WWF reserves near Manaus, Brazil. Pp. 426-454 in A. H. Gentry (ed.), Four Neotropical Rainforest. New Haven. Yale University Press.

Editor: Vanessa Kruth Verdade 
Appendix I. Voucher specimens collected at the study sites at Rio Daraá (D) and Rio Ayuanã (A).

Allobates femoralis (A: CZPB-AA 238), Allobates paleovarzensis (A: CZPB-AA 266-270; D: CTGA-N-487), Allobates sp. (D: CZPB-AA 215-219), Rhaebo guttatus (D: CZPB-AA 161-163), Rhinella cf. margaritifera (A: URCA-H 12732; D: URCA-H 12731), Rhinella marina (A: CZPB-AA 254; D: CZPB-AA 255), Pristimantis cf. ockendeni (A: CZPB-AA 275277), Pristimantis zeuctotylus (A: no voucher; D: CZPB-AA 125, 220), Boana cf. cinerascens (A: INPA-H 31680; D: INPA-H 31681), Boana cf. geographica (A: CZPB-AA 865, 871, 872, 874, 875, 877-882; D: CZPB-AA 160, 863, 864, 866-870, 873, 876, 883, 884), Boana wavrini (A: CZPB-AA 200; D: CZPB-AA 199), Dendropsophus minusculus (D: CZPB-AA 221, 823826), Dendropsophus cf. minutus (A: CZPB-AA 110, 115, 121; D: CZPB-AA 103-109, 111-114, 116-120; 122-124, 159), Dendropsophus parviceps (A: CZPB-AA 224, 228, 231-233; D: CZPB-AA 222, 223, 225, 226, 229, 230, 234), Dendropsophus sarayacuensis (A: CZPB-AA 271-274), Osteocephalus leprieurii (A: CZPB-AA 95, 96, 98; D: CZPB-AA 97, 129), Osteocephalus oophagus (A: CZPB-AA 241, 242, 244; D: CZPB-AA 2343), Osteocephalus planiceps (A: CZPB-AA 239240), Osteocephalus taurinus (A: CZPB-AA 246, 248, 250, 251, 853; D: CZPB-AA 245, 247, 249), Osteocephalus vilarsi (A: CZPB-AA 857; D: CZPB-AA 126-128; 854-856), Scinax sp. 1 (D: CTGA-N- 303-309), Scinax sp. 2 (A: CTGA-N342-342), Trachycephalus coriaceus (D: CZPB-AA 130-136), Trachycephalus cunauaru (D: CZPB-AA 235-236), Adenomera andreae (A: CZPB-AA 185, 186, 190; D: CZPB-AA 184, 187-189, 191), Leptodactylus knudseni (A: CZPB-AA 337-344; D: CZPB-AA 237, 336), Leptodactylus mystaceus (A: CZPB-AA 172, 176, 178, 180; D: CZPB-AA 171, 173-175, 177, 179, 181-183), Leptodactylus pentadactylus (A: CZPB-AA 253, 347-349, 351-353; D: CZPB-AA 350), Leptodactylus petersii (A: CZPB-AA 205; D: CZPB-AA 204), Leptodactylus rhodomystax (A: CZPB-AA 256, 260-262, 265; D: CZPBAA 257-259, 263, 264), Leptodactylus riveroi (A: CZPB-AA 208-212, 214; D: CZPB-AA 206, 207, 213), Lithodytes lineatus (A: CZPB-AA 1001), Physalaemus ephippifer (D: CZPB-AA 201-203), Callimedusa tomopterna (A: CTGA-N-492; D: CZPB-AA 155-158), Phyllomedusa bicolor (D: no voucher), Adelastes hylonomos (D: INPA-H 32510, CZPB-AA 605), Chiasmocleis hudsoni (D: CZPB-AA 137-154), Chiasmocleis ventrimaculata (A: CZPB-AA 99-102, 252), Ctenophryne geayi (A: CZPB-AA 168; D: CZPB-AA 164-167, 169, 170), Pipa pipa (A: CZPB-AA 193-195; D: CZPB-AA 192, 196198), Bolitoglossa sp. (A: CZPB-AA 227). 